\title{
Mortality of insects and quality of maize grains in hermetic and non-hermetic storage
}

\author{
Priscila C. Viebrantz ${ }^{1}$, Lauri L. Radunz ${ }^{2}$ \& Rafael G. Dionello ${ }^{1}$ \\ ${ }^{1}$ Universidade Federal do Rio Grande do Sul/Faculdade de Agronomia/Departamento de Fitossanidade. Porto alegre, RS. E-mail: priscilac.viebrantz@gmail.com \\ (Corresponding author); rafdionello@hotmail.com \\ ${ }^{2}$ Universidade Federal da Fronteira Sul. Erechim, RS. E-mail: laurilr@gmail.com
}

\section{Key words:}

grain storage

modified atmosphere

pest control

fungal incidence

density

\begin{abstract}
A B S T R A C T
Due to the need to improve the quality and safety of foods, chemical methods used to control grain pests have been replaced by alternative methods. For example, modified atmosphere within the storage units has been used. Therefore, the objective was to evaluate maize grain quality and mortality of insects of the species Sitophilus zeamais and Tribolium castaneum in hermetic and non-hermetic environments for 50 days of storage. The hermetic units consisted of polyethylene "bags" with capacity for $60 \mathrm{~kg}$. A cage with 20 adults of each species and $200 \mathrm{~g}$ of maize was placed inside each unit. The oxygen level was quantified every five days. Evaluations of insect mortality and survival occurred at 10, 20, 30, 40 and 50 days of storage. At 0,30 and 50 days, density, moisture and fungal incidence analyses were conducted. The airtight system is efficient in the control of insects, with satisfactory mortality values for both species. Insects favor the development of fungi during the storage, regardless of the storage system.
\end{abstract}

\section{Palavras-chave:} armazenamento de grãos atmosfera modificada controle de pragas incidência de fungos massa específica

\section{Mortalidade de insetos e qualidade de grãos de milho em armazenamento hermético e não-hermético}

\section{R E S U M O}

Devido à necessidade de melhorar a qualidade e a segurança dos alimentos, a utilização de métodos químicos para o controle de pragas de grãos tem sido substituída por métodos alternativos; tem-se, como exemplo, o uso da atmosfera modificada no interior das unidades armazenadoras; portanto, o objetivo do trabalho foi avaliar a qualidade de grãos de milho e a mortalidade de insetos das espécies Sitophilus zeamais e Tribolium castaneum em ambiente hermético e não hermético, durante 50 dias de armazenamento; as unidades herméticas consistiam de "bags" de polietileno com capacidade de $60 \mathrm{~kg}$; no interior de cada unidade foi colocada uma gaiola contendo 20 insetos adultos de cada espécie e $200 \mathrm{~g}$ de milho; a cada cinco dias quantificou-se o nível de oxigênio; as avaliações de mortalidade e sobrevivência dos insetos foram realizadas aos 10, 20, 30, 40 e 50 dias de armazenamento; aos 0, 30 e 50 dias foram analisados a massa específica, teor de água e incidência de fungos; o sistema hermético foi eficiente quanto ao controle dos insetos apresentando valores satisfatórios de mortalidade para ambas as espécies; insetos favorecem o desenvolvimento de fungos ao longo do armazenamento, independentemente do sistema de armazenagem. 


\section{INTRODUCTION}

The performance of grain production has not been followed by improvements in agricultural marketing services, specifically in storage and transport, which in part has disappointed the competitiveness conditions of the Brazilian product in the domestic and international markets (Nogueira Júnior \& Tsunechiro, 2003).

According to CONAB (2015), the total static capacity registered in Brazil is 150.2 million tons, distributed in the modalities of conventional warehouses with 23.6 million tons and grain warehouses with 126.6 million tons, representing 15.7 and $84.3 \%$, respectively; conventional storage predominantly uses structures such as warehouses of simple construction, of masonry, with grain storage in sacks.

Grain losses occur mostly due to storage pest attack and also due to the presence of rodents, birds and fungi contamination (Athié, 1998). According to Pinto Jr. (2011), the presence of insects in agricultural products has great economic importance because of the different damages caused or the contamination with their fragments, resulting in negative goodwill and, in some cases, in the refusal of the product for marketing. Among the main insects of stored grains are the coleopteran Sitophilus zeamais and Tribolium castaneum (Elias et al., 2009).

One possibility for the management of insects and for maintaining quality in storage is to use a physical method, by modifying the storage atmosphere. The hermetic storage of grains in sealed bags has been an effective method to control moisture and insects in grains, which restricts gas exchanges between the internal and external environments and the mass of grain, maintaining the initial levels of moisture and controlling pests by the lack of oxygen (Quezada et al., 2006).

According to Rupollo et al. (2006), the bulk storage through the packaging of dried beans in sealed units is based on reducing the available oxygen in the ecosystem to lethal or limiting levels for the living organisms. This reduction can occur spontaneously, through the activity related to gas exchange of the respiration of grains and organisms, allowing the hermetic storage of bulk grain to be a way to reduce the attack of insects and fungi. Therefore, this study aimed to evaluate the fungal incidence, physical quality and mortality of the insect species Sitophilus zeamais and Tribolium castaneum in maize grains maintained in hermetic and non-hermetic environments.

\section{Material AND Methods}

The experiment was conducted in the Grain Postharvest Laboratory of the Plant Health Department, at the Faculty of Agronomy of the Federal University of Rio Grande do Sul (UFRGS) during the period from October to November 2013.

Maize grains with $13 \%$ moisture content on a wet basis (wb) and stored in two ways were used. The grains were stored as follows: 1. Hermetic storage in plastic bags, provided by the company Superbag (GrainPro, INC.), and 2. Storage using the bags in a non-hermetic way, that is, open. For the two storage conditions, 10 bags were used in two replicates, totaling 20 experimental units. The storage period was 50 days, with five evaluation periods.
Unsexed adult insects aged between 20 and 50 days from the species $S$. zeamais and T. castaneum, raised in a room with controlled conditions of temperature $\left(25 \pm 5^{\circ} \mathrm{C}\right)$ and humidity $(60 \pm 10 \%)$ located in the Department of Plant Protection, were used.

Each storage unit contained a PVC cage with 20 adult insects of each species, totaling 40 insects; each cage with the insects received $200 \mathrm{~g}$ of maize as food substrate; these cages were previously closed with voile fabric at the ends to allow gas exchange and prevent the escape of insects; soon after, the cages were deposited within the grain mass, in the center of each storage unit, in both hermetic and non-hermetic systems.

Two units of each storage system (hermetic and nonhermetic) were evaluated every 10 days, totaling 20 bags at the end of the 50 days; the presence of insects was evaluated in 10-day intervals by withdrawing and opening the cages with immediate counting of the insects.

For counting the insects, the material from each cage was placed on trays and dead and alive insects were carefully observed in order to obtain data from each replicate. The product that did not present any live insect was considered as free of insects, as recommended by Lorini (2008).

During the storage period, oxygen concentration evaluations were conducted every five days, inside the bags, using a gas meter (GrainPro).

To evaluate the quality of the infected maize grains, apparent density and fungi incidence analyses were conducted at the time of experiment installation and at 30 and 50 days of storage.

The apparent density of the grains was determined by weighing on an electronic scale with a precision of $0.001 \mathrm{~g}$, in a container of known volume, with three replicates for each storage; finally, the results were converted to be expressed in $\mathrm{kg} \mathrm{m}^{-3}$.

To determine the moisture content of the grains, the method of the oven drying at $105+3{ }^{\circ} \mathrm{C}$ with natural air circulation was used for a total period of 24 hours, as indicated in the Rules for Seed Analysis (Brazil, 2009). Three replicates were used with $10 \mathrm{~g}$ of maize for each storage; the results were expressed as percentage of moisture content, on wet basis.

The evaluation of fungal incidence in the samples was performed using filter paper method known as "Blotter Test" method, according to the methodology recommended for analysis of maize seeds (Brazil, 2009) and evaluated in percentage of fungi from the genus Aspergillus spp., Fusarium spp. and Penicillium spp., besides being calculated from the number of grains contaminated with fungi in each replicate. From an adaptation of the methodology described above, with reduced number of grains, each storage consisted of eight replicates of 25 grains, totaling 200 grains per storage; the containers with the grains were placed under white fluorescent light bulbs in a growth chamber with a photoperiod of 12 hours at a temperature of $20 \pm 2{ }^{\circ} \mathrm{C}$ for a period of 7 days. Identification of fungi was carried out with the aid of a stereoscopic loupe; the results were expressed as percent incidence of each genus.

The data were submitted to variance analysis (F test) and, when significant effect was observed, quantitative factors 
were submitted to Tukey test $(\mathrm{p} \leq 0.05)$ and quantitative factors to non-linear regression analysis using the programs Assitat $7.7^{\circ}$ and SigmaPlot $10.0^{\circ}$, respectively.

\section{Results AND Discussion}

In the analysis of moisture content in the grains, significant effect of the variable time ( $\mathrm{p}=0.000011$ ) was observed; in the beginning of storage, the moisture content was $12.68 \%$ and at the end of 50 days of storage, it was $13.31 \%$; as the difference only occurred for the variable time, this mean refers to all the experimental units (hermetic and non-hermetic storage).

This variation was probably due to the tendency of the grains to come to hygroscopic equilibrium with the storage environment. This effect of loss or gain of water as a function of environmental conditions was also observed by other authors, for example, Schuh et al. (2011). Slight variations of the moisture content in hermetic storage of seeds were also observed by other authors evaluating the quality of Crambe abyssinica during storage in containers (Masetto et al., 2013; Bezerra et al., 2015).

In the variance analysis, for the oxygen content in the hermetic system, significant variation between time zero $(20.8 \%)$ and other evaluation times $(\mathrm{p}=0.0001)$ was verified. It is observed that the largest variation occurred between time zero and the first five days of storage when the concentration of intergranular oxygen reduced from 20.8 to $6.1 \%$ (Figure 1 ); however, between the evaluations conducted at five days and 50 days, there were no significant changes in oxygen concentration as it reduced only from 6.1 to $3.86 \%$.

According to Muir et al. (2001), in hermetic storage, living organisms comprising the ecosystem consume oxygen through the respiratory process, with the reduction of oxygen and change of the gaseous atmosphere inside hermetic structures, i.e. bags. Aguiar et al. (2004) observed that the time required for $\mathrm{O}_{2}$ consumption in an environment is directly proportional to the moisture content and temperature of the stored product.

Regarding the insect mortality, it was observed through the $\mathrm{F}$ test that the hermetic system was more effective in

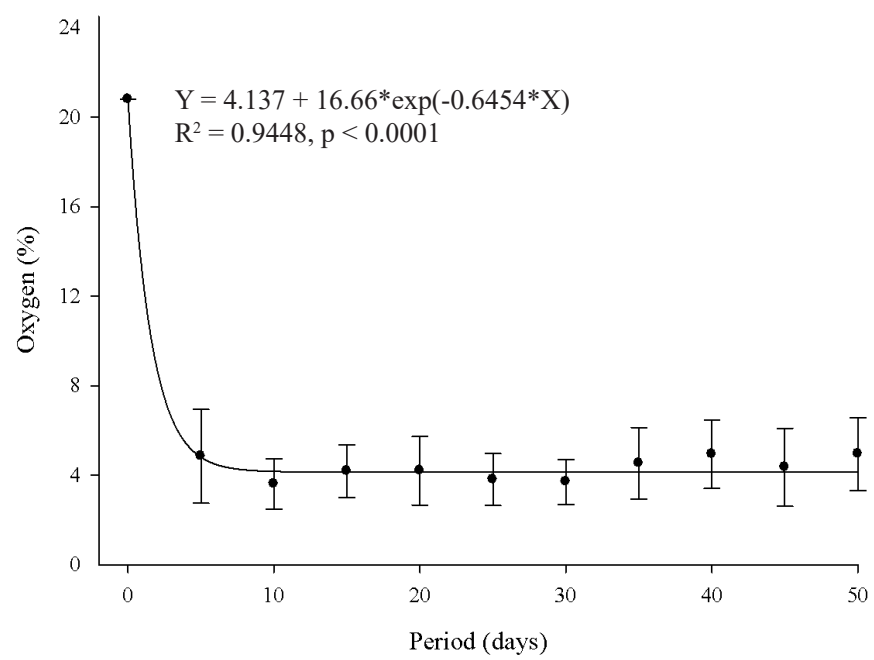

Figure 1. Intergranular oxygen content (\%) in hermetically stored maize infested with Sitophilus zeamais and Tribolium castaneum for 50 days controlling both species (Table 1). The mortality observed in non-hermetic storage may be related to the age of the insects used in this experiment, which may have died in a natural way when completing their life cycle; the longevity of this species is approximately 140.5 days for females and 142 days for males (Sousa et al., 2009).

The survival was higher in the non-hermetic system for both insect species (Table 2). As the mean oxygen content during the 50 days of storage was around 5\% in the hermetic environment, it is believed that this amount was sufficient for a satisfactory insect mortality in relation to non-hermetic storage, although this mortality did not reach $100 \%$.

According to Moreno et al. (2000), insects die when the percentage of intergranular oxygen of maize grains reaches $3 \%$ or less. In the study of mortality of S. zeamais in hermetically stored maize, this author states that insects are the ones that consume more oxygen, followed by fungi and then the grains themselves. Thus, the continuous consumption of oxygen creates an unfavorable environment since the respiration process consumes $\mathrm{O}_{2}$ and produces $\mathrm{CO}_{2}$, becoming lethal to insects depending on the concentration. In this case, the most responsible factor for the death of the insects in a controlled or modified atmosphere is the lack of oxygen (Fleurat-Lessard, 2002).

For effective control, $\mathrm{O}_{2}$ levels should be less than $3 \%$ and preferably less than $1 \%$ if a rapid control of insects is needed (Navarro, 2012). Thus, as the oxygen levels found in this study for the hermetic system were up to $3 \%$, i.e. around $4 \%$ after the period of 50 days of storage, this fact may have influenced mortality, causing it not to reach levels close to $100 \%$.

Bailey (1955) noted that, although the suppression of insect development has been observed in environments with about $5 \%$ of $\mathrm{O}_{2}$, the exposure time necessary to eliminate the insects is longer, which may explain the observed mortality rate in the 50 days of the study analyzed.

For the apparent density, only single effects for the factors storage time $(\mathrm{p}=0.004784)$ and storage system $(\mathrm{p}=0.009775)$ were observed, and the interaction effect was not significant according to the $\mathrm{F}$ test.

Table 1. Sitophilus zeamais and Tribolium castaneum mean mortality values in non-hermetic and hermetic storage for 50 days

\begin{tabular}{|c|c|c|c|c|}
\hline \multirow{3}{*}{ Treatment } & \multicolumn{4}{|c|}{ Mortality (\%) } \\
\hline & \multicolumn{2}{|c|}{ Sitophilus zeamais } & \multicolumn{2}{|c|}{ Tribolium castaneum } \\
\hline & Mean & Standard error & Mean & Standard error \\
\hline Hermetic & $78.5 a^{*}$ & 9.6 & $70.0 a^{\star}$ & 11.6 \\
\hline Non-hermetic & $14.0 b^{\star}$ & 5.0 & $20.5 b^{\star}$ & 4.5 \\
\hline
\end{tabular}
$(p \leq 0.05)$ and asterisk $\left(^{*}\right)$ in the line do not differ by t test $(p \leq 0.05)$

Table 2. Sitophilus zeamais and Tribolium castaneum mean survival values in non-hermetic and hermetic storage for 50 days

\begin{tabular}{|c|c|c|c|c|}
\hline \multirow{3}{*}{ Treatment } & \multicolumn{4}{|c|}{ Survival (\%) } \\
\hline & \multicolumn{2}{|c|}{ Sitophilus zeamais } & \multicolumn{2}{|c|}{ Tribolium castaneum } \\
\hline & Mean & Standard error & Mean & Standard error \\
\hline Hermetic & $21.5 b^{\star}$ & 9.6 & $30.0 b^{*}$ & 11.6 \\
\hline Non-hermetic & $86.0 a^{*}$ & 5.0 & $79.5 a^{*}$ & 4.5 \\
\hline
\end{tabular}

Means followed by the same letter in the column do not differ statistically by Tukey test $(p \leq 0.05)$ and asterisk $\left(^{*}\right)$ in the line do not differ by $t$ test $(p \leq 0.05)$. 
According to the regression analysis, during the storage period, there was significant variation in the apparent density, regardless of the system $\left(y=639.38+0.4957^{*} X-0.0135^{\star} X^{2}\right.$, $\mathrm{R}^{2}=0.32 ; \mathrm{p}=0.0233$ ), whereas up to 30 days there was a slight increase with further reduction by the end of the storage period.

The mean values of apparent density were $640.97 \mathrm{~kg} \mathrm{~m}^{-3}$ (hermetic) and $633.56 \mathrm{~kg} \mathrm{~m}^{-3}$ (non-hermetic) (Table 3). The non-hermetic treatment had the lowest density compared to the hermetic treatment, which occurred due to the higher intensity of pest attack, since the survival of both insect species was greater in non-hermetic system.

The results are in agreement with those of other authors, such as Almeida Filho et al. (2002), who reviewed the mass reduction in different maize cultivars infested with Sitophilus zeamais and S. oryzae over 180 days of storage and asserted that the mass losses caused by insects in maize grains are closely related to the affinity of these pests to the maize cultivars. Ali et al. (2011) observed weight loss in maize due to the infestation of S. zeamais for 120 days of storage, with differences in the initial value in the three periods of storage (60,90, and 120 days).

Ferrari Filho et al. (2012) also obtained similar results evaluating the quality of wheat during the hermetic and conventional storage for nine months and found that there was a reduction of the apparent density of grains stored in sacks because of insect attack, presence of microorganisms and the metabolic activity of these grains; grains that have been stored in a sealed system had higher apparent density values along the storage.

In the analysis of contamination by Fusarium spp., according to the $\mathrm{F}$ test, there was double interaction effect of time $\mathrm{x}$ storage system $(\mathrm{p}=0.006258)$. For both storage systems, there was a significant variation in fungal incidence ( $\mathrm{p}<0.0001)$; in non-hermetic system, a higher incidence of Fusarium spp. was observed, ranging from 0 to $16 \%$, while in the hermetic system, it varied from 0 to $4.1 \%$ during the storage period (Figure 2). For both systems, an increase was found in the incidence of this fungus to about 30 days of storage with reduction from that moment until the end of the period.

This increase in the development of Fusarium spp. is not similar to what was observed by Marcia \& Lazzari (1998); the authors state that this genus, considered as a field fungus, invades grain during the ripening and the damage is caused before the harvest; furthermore and according to the authors, this fungus does not grow during storage, except occasionally in stored maize with high moisture content. However, results similar to those of this study were observed by Tiecker (2013), who found a high incidence of Fusarium spp. in maize grains

Table 3. Mean values of apparent density of maize grains infested with Sitophilus zeamais and Tribolium castaneum in non-hermetic and hermetic storage for 50 days

\begin{tabular}{cc}
\hline Storage system & Apparent density $\left(\mathrm{kg} \mathrm{m}^{-3}\right)$ \\
Non-hermetic & $633.56 \mathrm{~b}$ \\
Hermetic & $640.97 \mathrm{a}$ \\
CV (\%) & 0.80 \\
\hline
\end{tabular}

Means followed by the same letter do not differ statistically by Tukey test ( $p \leq 0.05)$

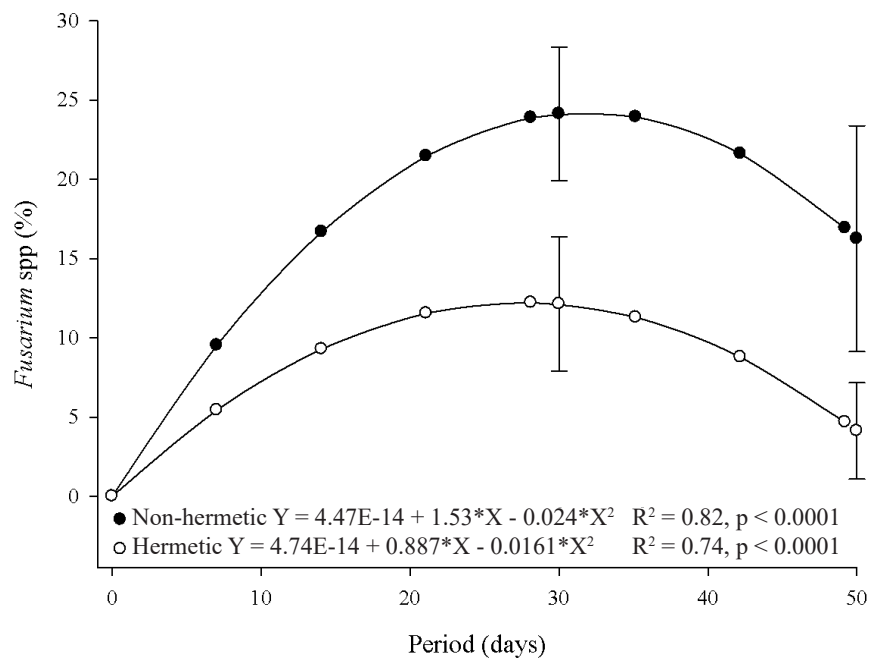

Figure 2. Contamination by Fusarium spp. (\%) in maize stored in non-hermetic and hermetic systems and infested with Sitophilus zeamais and Tribolium castaneum for 50 days

hermetically and conventionally kept over eight months of storage.

For a long time, Fusarium spp. was considered as only a field pathogen, but it is now known that Fusarium verticillioides, for example, can persist in the grains after harvest, during the transport and continue its growth during the storage (Marin et al., 2004; Chulze, 2010).

Telles Neto et al. (2007), when evaluating the viability of Fusarium graminearum in wheat seeds during storage, observed a reduction in the contamination, and at 12 months of storage the incidence was $0 \%$; however, in the present study, after 30 days of storage, a reduction in the incidence of this fungus was observed, but the behavior for a longer storage period cannot be affirmed.

Although initial growth was observed, for both systems, this growth was lower in the hermetic system, as well as the final incidence, showing that low oxygen rates may reduce the growth of microorganisms. According to Weinberg et al. (2008), this environment kills insects and mites and prevents the growth of aerobic fungi.

In contamination by Penicillium spp., only single effect of the factor time was observed according to the F test $(\mathrm{y}=$ $11.0969^{*}\left(1-\exp \left(-0.1155^{*} \mathrm{X}\right)\right) \mathrm{R}^{2}=0.59$ and $\left.\mathrm{p}=0.000115\right)$. It is noted that the growth of this fungus occurred until 30 days of storage, regardless of the system used, with higher stability in its development $(\mathrm{p}<0.0001)$.

Among the factors that affect fungal growth in maize, there is the presence of not only insects but also mites, and the invasion of a lot of grains by insects can initiate or aggravate the development of fungi (Miller, 1995). Due to the presence of pests in the grain mass, the growth of fungi was favored, a fact that confirms what was described by the author.

For the incidence of Aspergillus spp., according to the $\mathrm{F}$ test, only single effect for the factor time $(\mathrm{p}=0.0000001)$ was also observed. Over the 50 days of storage, there was a significant increase in the incidence of this fungus $(\mathrm{p}<$ 0.0001 ), regardless of the storage system, ranging from 0 to $36.5 \%$ (Figure 3). 


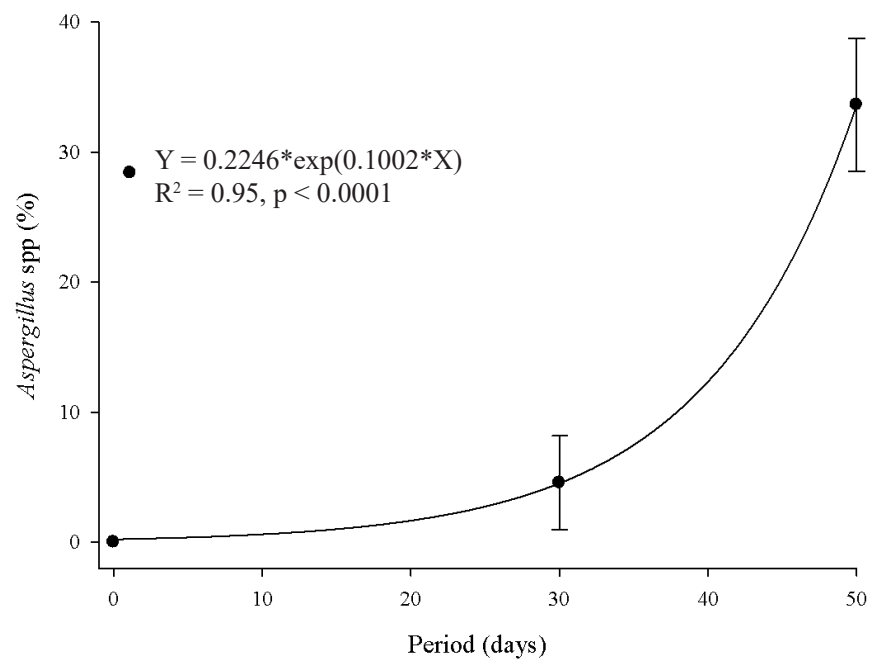

Figure 3. Fungal contamination by Aspergillus spp. (\%) in maize stored in non-hermetic (open) and hermetic systems and infested with Sitophilus zeamais and Tribolium castaneum for 50 days

These results are consistent with the conclusions of Tiecker (2013). The author observed an increase of fungi of the genus Aspergillus in maize grains over the period, regardless of the storage system (hermetic and non-hermetic). According to Moreno et al. (2000), fungal growth ceases when the oxygen content reaches about $1 \%$. Since in this experiment the oxygen levels remained above $4 \%$, the determined concentration of $\mathrm{O}_{2}$ may not have been sufficient to reduce fungal contamination during the storage period.

Despite the low levels of oxygen found, there was the development of the fungi Penicillium spp. and Aspergillus spp., corroborating with the findings of Magan \& Lacey (1984). These authors state that there may be fungal growth even during the storage under conditions of low oxygen levels in the environment, suggesting that other factors are often more important than the levels of oxygen and carbon dioxide during storage of these grains.

This fungal development can be related to the fact that the amount of oxygen required for the growth of several fungal species is extremely low and the growth of some species of Penicillium and Aspergillus is only lowered when the oxygen content is below $0.5 \%$ (Miller \& Golding, 1949). As oxygen levels in the experiment were above this value, it may not have been a limiting factor for fungal development.

Also as explained above, the presence of insects in the grain mass promotes the spread of fungi, since they can carry their spores inside the grain mass (Wetzel, 1987), which may have contributed to the increase in their incidence.

\section{Conclusions}

1. The hermetic system is efficient for insect pest control with satisfactory values of mortality for both species evaluated (Sitophilus zeamais and Tribolium castaneum).

2. The attack of pests in storage results in the reduction of the density of the grains, mainly in the non-hermetic storage system.

3. The presence of insects favors the development of fungi during the storage, regardless of the storage system.

\section{Literature Cited}

Aguiar, R W. S.; Sarmento, R. A.; Vieira, S. M.; Didonet, J. Controle de pragas em grãos armazenados utilizando atmosfera modificada. Bioscience Journal, v.20, p.21-27, 2004.

Ali, Q.; Ahsan, M.; Tahir, M. H. N.; Waseem, M.; Farooq, J.; Elahi, M.; Sadique, M. Genetic variability for grain yield and quality traits in chickpea (Cicer arietinum L.). International Journal for Agro Veterinary and Medical Sciences, v.5, p.201-208, 2011. http:// dx.doi.org/10.5455/ijavms.20110521104936

Almeida Filho, A. J., Fontes, L. S., Arthur, V. Determinação da perda de peso do milho (Zea mays) provocada por Sitophilus oryzae e Sitophilus zeamais. Revista Ecossistema, v.27, p.41-44, 2002.

Athié, I. Conservação de grãos. Campinas: Fundação Cargill, 1998. 236p.

Bailey, S. W. Air-tight storage of grain: Its effect on insect pests. I. Calandra granaria L. (Coleoptera, Curculionidae). Australian Journal Agricultural. Research, v.6, p.33-51, 1955. http://dx.doi. org/10.1071/AR9550033

Bezerra, P. H. S.; Biaggioni, M. A. M.; Silva, M. A. P.; Sperotto, F. C. S.; Brandão, F. J. B. Efeito do armazenamento na qualidade dos grãos e do óleo de crambe para produção de biodiesel. Energia na Agricultura, v.30, p.310-318, 2015. http://dx.doi.org/10.17224/ energagric.2015v30n3p310-318

Brasil. Ministério da Agricultura Pecuária e Abastecimento (MAPA). Regras para análise de sementes. Brasília: Mapa/ACS, 2009. 399p.

Chulze, S. N. Strategies to reduce mycotoxin levels in maize during storage: a review. Food Additives and Contaminants, v.7, p.651657, 2010. http://dx.doi.org/10.1080/19440040903573032

CONAB - Companhia Nacional de Abastecimento. Capacidade estática cadastrada no Brasil. 2015. <http://sisdep.conab.gov.br/ capacidadeestatica/>. 11 Mar. 2015.

Elias, M. C.; Lorini, I.; Mallamann, C. A.; Dilkin, P.; Oliveira, M.; Mallmann, A. O. Manejo integrado no controle de pragas de grãos e derivados. In: Elias, M. C.; Oliveira, M. Aspectos tecnológicos e legais na formação de auditores técnicos do sistema nacional de certificação de unidades armazenadoras. Pelotas: Santa Cruz, 2009. p. 305-353.

Ferrari Filho, E.; Antunes, L. E. G.; Gottardi, R.; Dionello, R. G.; Petry, P. A. R.; Barreto, G. P. Qualidade de grãos de trigo submetidos a diferentes condições de armazenamento. Pesquisa Agropecuária Gaúcha, v.18, p.25-35, 2012.

Fleurat-Lessard, F. Qualitative reasoning and integrated management of the quality of stored grain: a promising new approach. Journal of Stored Products Research, v.38, p.191-218, 2002. http://dx.doi. org/10.1016/S0022-474X(01)00022-4

Lorini, I. Manejo integrado de pragas de grãos de cereais armazenados. Passo Fundo: Embrapa Trigo, 2008. v.2. 71p.

Magan, N.; Lacey, J. Effects of gas composition and water activity on growth of field and storage fungi and their interactions. Transactions of the British Mycological Society, v.82, p.305-314, 1984. http://dx.doi.org/10.1016/S0007-1536(84)80074-1

Márcia, B. A.; Lázzari, F. A. Monitoramento de fungos em milho em grão, grits e fubá. Ciência e Tecnologia de Alimentos, v.18, p.363-367,1998.

Marin, S.; Magan, N.; Ramos, A. J.; Sanchis, V. Fumonisin producing strains of Fusarium: a review of their ecophysiology. Journal of Food Protection, v.67, p.1792-1805, 2004. 
Masetto, T. E.; Gordin, C. R. B.; Quadros, J. de B.; Rezende, R. K. S.; Scalon, S. de P. Q. Armazenamento de sementes de Crambe abyssinica Hochst. ex R.E.Fr . em diferentes embalagens e ambientes. Revista Ceres, v.60, p.646-652, 2013. http://dx.doi. org/10.1590/S0034-737X2013000500007

Miller, D. D.; Golding, N. S. The gas requirements of molds: V. the minimum oxygen requirements for normal growth and for germination of sir mold cultures. Journal of Dairy Science, v.32, p.101-110, 1949. http://dx.doi.org/10.3168/jds.S00220302(49)92017-2

Miller, J. D. Fungi and mycotoxins in grain:implications for stored product research. Journal Stored Products Research, v.31, p.1-16, 1995. http://dx.doi.org/10.1016/0022-474X(94)00039-V

Moreno, M. E.; Jimenez, A. S.; Vazquez, M. E. Effect of Sitophilus zeamais and Aspergillus chevalieri on the oxygen level in maize stored hermetically. Journal of Stored Products Research, v.36, p.25-36, 2000. http://dx.doi.org/10.1016/S0022474X(99)00023-5

Muir, W. E.; Jayas, D. S.; White, N. D. G. Controlled atmosphere storage. In: Muir, W. E. (ed.) Grain preservation biosystems. Manitoba: [s.n.], 2001. 421p.

Navarro, S. Advanced grain storage methods for quality preservation and insect control based on aerated or hermetic storage and IPM. Journal of Agricultural Enginnering, v.49, p.13-20, 2012.

Nogueira Junior, S.; Tsunechiro, A. Descompasso entre produção e armazenagem de grãos. IEA - Instituto de economia agrícola. 2003. <http://www.iea.sp.gov.br/out/verTexto.php?codTexto=883>. 16 Mai.2013.

Pinto Jr., A.R. Eficiência de terra de diatomáceas no controle de Sitophilus oryzae (L.), Cryptolestes ferrugineus (Stephens), Tribolium castaneum (Herbst) em milho armazenado a granel. Revista da Faculdade de Zootecnia, Veterinária e Agronomia, v.15, p.61-70, 2008
Quezada, M. Y.; Moreno, J.; Vazquez, M. E.; Mendoza, M., Mén10Albores, A.; Moreno, M. E. Hermetic storage system preventing the proliferation of Prostephanus truncatus Horn and storage fungi in maize with different moisture contents. Postharvest Biology and Technology, v.39, p.321-326, 2006. http://dx.doi.org/10.1016/j. postharvbio.2005.10.004

Rupollo G.; Gutkoski, L. C.; Marni, L. J.; Elias, M. C. Efeito da umidade e do período de armazenamento hermético na contaminação natural por fungos e a produção de micotoxinas em grãos de aveia. Ciência e Agrotecnologia, v.30, p.118-125, 2006. http:// dx.doi.org/10.1590/S1413-70542006000100017

Schuh, G.; Gottardi, R.; Ferrari, E. F.; Antunes, L. E. G.; Dionello, R. G. Efeitos de dois métodos de secagem sobre a qualidade físicoquímica de grãos de milho safrinha-RS, armazenados por 6 meses. Semina: Ciências Agrárias, v.32, p.235-244, 2011. http://dx.doi. org/10.5433/1679-0359.2011v32n1p235

Sousa, A. H.; D’antonino Faroni, L. R.; Pimentel, M. A. G.; Guedes, R. N. C. Developmental and population growth rates of phosphine resistant and susceptible populations of stored product insect pests. Journal of Stored Products Research, v.45, p.241-246, 2009. http://dx.doi.org/10.1016/j.jspr.2009.04.003

Telles Neto, F. X. de B.; Reis, E. M.; Casa, R. T. Viabilidade de Fusarium graminearum em sementes de trigo durante o armazenamento. Summa Phytopathology, v.33, p.414-415, 2007. http://dx.doi. org/10.1590/S0100-54052007000400017

Tiecker, A. Avaliação da qualidade de grãos de milho e soja em armazenamento hermético e não hermético sob diferentes umidades de colheita. Porto Alegre: UFRGS, 2013. 83p. Dissertação Mestrado

Weinberg, Z.G., Yan, Y.; Chen, Y.; Finkelman, S.; Ashbell, G.; Navarro, $\mathrm{S}$. The effect of moisture level on high-moisture maize (Zea mays L.) under hermetic storage conditions-in vitro studies. Journal of Stored Products Research, v.44, p.136-144, 2008. http:// dx.doi.org/10.1016/j.jspr.2007.08.006

Wetzel, M. M. V. S. Fungos de Armazenamento. In: Soave, J.; Wetzel, M. M. Vh. S. (ed.). Patologia de sementes. Campinas: Fundação Cargill, 1987. p.562-568. 